\title{
PENIADAAN SALAT JUMAT DALAM SURAT EDARAN GUBERNUR SULSEL NOMOR: 451.11/2057/2020 SELAMA PANDEMI COVID-19

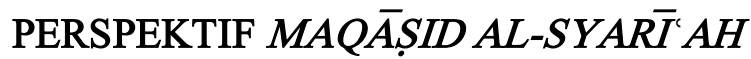

\section{DISMISSAL OF FRIDAY PRAYERS IN CIRCULAR LETTER OF SOUTH SULAWESI GOVERNOR NUMBER: 451.11 / 2057/2020 DURING COVID-19 PANDEMIC FROM THE PERSPECTIVE OF MAQĀSID AL-SYARI'AH}

\author{
Sirajuddin \\ Sekolah Tinggi Ilmu Islam dan Bahasa Arab (STIBA) Makassar \\ Email: sirajuddin@stiba.ac.id \\ Kasjim Salenda \\ Universitas Islam Negeri (UIN) Alauddin Makassar \\ Email: kasjim.salenda@gmail.com
}

\author{
Abdul Wahid Haddade \\ Universitas Islam Negeri (UIN) Alauddin Makassar \\ Email: ibnuhaddade@gmail.com
}

\section{Keywords : \\ Maqāsid al-Syarīah, Circular} Letter, Friday Prayers, COVID-19.
This research aimed to analyze the relevance of dismissal of friday prayers in circular letter of south sulawesi governor number: 451.11 / 2057/2020 during covid-19 pandemic from the perspective of maqasid al-syari' ah. This research is library research using a qualitative approach and content analysis techniques. The results of the research conclude that the substance of the circular letter is relevant to the principle of maqasid al-syari ah which is the core philosophy of the formation of Islamic law in presenting the benefit of mankind in the world and the hereafter, both from the aspect of maqā $s$ id al-kulliyyah (universal) and maqā $s$ id al-juz'iyyah (partial) especially maqā $s$ id in obeying a leader. Therefore, the emergence of the phenomenon of counter attitudes from some people and even preachers towards the policy should not occur

Kata kunci :

Maqāsid al-Syarī'ah, Surat Edaran, Salat Jumat, COVID-19. ABSTRAK

ABSTRAK

Penelitian ini bertujuan untuk menganalisis relevansi peniadaan ibadah Salat Jumat yang tercantum dalam Surat Edaran Gubernur Sulsel Nomor: 451.11/2057/2020 selama masa pandemi Covid-19 dengan prinsip maqāsid al-syarī ah. Penelitian ini adalah penelitian kepustakaan (library research) dengan menggunakan metode pendekatan kualitatif dan teknik analisis isi (content analysis). Hasil penelitian menyimpulkan bahwa, substansi surat edaran tersebut relevan dengan prinsip maqāsid al-syari’ah yang merupakan filosofi inti pembentukan syariat Islam dalam menghadirkan kemaslahatan manusia di dunia dan di akhirat, baik dari aspek maqāsid al-kulliyyah (universal) maupun maqāsid al-juz'iyyah (parsial) khususnya maqāsid dalam menaati pemimpin, sehingga kemunculan fenomena sikap kontra dari sebagian masyarakat bahkan dari kalangan mubalig terhadap kebijakan tersebut seharusnya tidak 
How to cite : Sirajuddin. S., Salenda, K., Haddade, A. W. (2020). Peniadaan Salat Jumat dalam Surat Edaran Gubernur SULSEL Nomor: 451.11/2057/2020 Selama Pandemi Covid-19 Perspektif Maqāșid al-Syarī 'ah NUKHBATUL 'ULUM: Jurnal Bidang Kajian Islam, 6(2), 289-309. https://doi.org/10.36701/nukhbah.v6i2.218

\section{PENDAHULUAN}

Setiap pemimpin bertanggung jawab dalam menghadirkan kemaslahatan untuk rakyatnya. Segala tindakannya juga berorientasi dalam menghadirkan kesejahteraan dan ketenteraman dengan menyediakan kebutuhan-kebutuhan dan fasilitas-fasilitas penunjang keberlangsungan hidup mereka, termasuk dalam menjaga keamanan dan keselamatan jiwa ${ }^{1}$. Prinsip tersebut sejalan dengan konsep kepemimpinan dalam syariat Islam. Nabi saw. dalam sebuah hadisnya yang diriwayatkan oleh sahabat Ma'qil bin Yasār r.a. telah menyebutkan ancaman keras berupa diharamkannya surga atas pemimpin yang wafat dalam keadaan menipu rakyatnya ${ }^{2}$. Meskipun demikian, rakyat juga dituntut untuk memiliki pemahaman yang benar tentang bagaimana menjadi orang-orang yang dipimpin agar tidak keliru dalam menyikapi kebijakan-kebijakan pemimpinnya.

Sebuah kebijakan pemimpin oleh sebagian masyarakat kadang dipandang kontraproduktif dalam menghadirkan kemaslahatan bagi mereka terutama jika kebijakan itu terkait persoalan prinsip, seperti persoalan pelaksanaan ritual keagamaan. Dalam agama Islam, kebanyakan persoalan-persoalan fikih yang bersifat 'amali (ibadah praktis) adalah qābilatun li al-niqāsy (bisa diperdebatkan). Kecenderungannya, jika seorang pemimpin menetapkan salah satu di antara pendapat tersebut sebagai dasar kebijakan, maka akan mengundang perbedaan persepsi, bahkan sikap menyimpang di tengah masyarakat. Seperti fenomena sikap kontra sebagian masyarakat terhadap kebijakan pemerintah tentang peniadaan pelaksanaan Salat Jumat selama masa penyebaran penyakit Coronavirus Disease 2019 atau COVID-19.

Penyakit Coronavirus Disease 2019 (COVID-19) ditemukan pada akhir tahun 2019 dan menjadi pandemi global di awal tahun 2020. Penyakit ini diasebabkan oleh sebuah virus mematikan yang pertama kali ditemukan di Wuhan, Tiongkok. Virus ini diberi nama oleh World Health Organization (WHO) dengan Severe Acute Respiratory Syndrome Coronavirus-2 (SARS-

${ }^{1}$ Usman, M. H., Aswar, A., \& Irawan, A. W., "Syariat Islam dan Kemaslahatan Manusia di Era New Normal pada Kegiataan Keagamaan dan Pendidikan”, FENOMENA, 12 no. 1 (2020): h. 90 .

${ }^{2}$ Yaḥya ibn Syarf al-Nawawi, Saḥihh Muslim bi Syarh al-Nawawī, Jilid. 2 (t.t: Dār alTaqwā li al-Nasyr wa al-Tauzi'’, t.th), h. 330, hadis no. 142. 
CoV-2) dan penyakitnya bernama Coronavirus Disease 2019 (COVID-19) ${ }^{3}$. Virus ini sendiri telah menelan korban ratusan ribu orang, sehingga World Heath Organization (WHO) menetapkannya sebagai bencana pandemi internasional. Menurut data WHO, pada tanggal 16 April 2020 M jumlah korban yang terdeteksi positif COVID-19 sebanyak 1.991 .562 orang, dan wafat sebanyak 130.885 orang, dari 213 negara $^{4}$, termasuk Indonesia. Kematian yang terjadi lintas wilayah di Indonesia yang diakibatkan oleh COVID-19 menunt ut Presiden Jokowi untuk mengeluarkan keputusan penetapan kedaruratan kesehatan masyarakat COVID-19 pada tanggal 31 Maret $2020^{5}$ dan ditetapkannya sebagai bencana nasional pada tanggal 13 April $2020^{6}$.

Di antara Pemerintah Daerah yang melakukan tindakan cepat, tanggap darurat dalam menanggulangi penyebaran virus ini adalah Pemerintah Daerah Sulawesi Selatan dengan mengeluarkan Surat Edaran No. 451.11/2057/2020 tentang imbauan kepada masyarakat Sulawesi Selatan terkait pelaksanaan kegiatan keagamaan di Sulawesi Selatan. Surat edaran ini sebenarnya dijiwai berdasarkan fatwa yang dikeluarkan oleh Majenlis Ulama Indonesia (MUI) pada tanggal 16 Maret $2020 \mathrm{M}$, yang di dalamnya terdapat imbauan peniadaan pelaksanaan Salat Jumat selama dua pekan (Jumat 20 Maret dan Jumat 27 Maret $2020 \mathrm{M})$ dan diganti dengan salat zuhur di rumah.

Dalam implementasi Surat Edaran Gubernur Sulsel tersebut, tampak mencuat ke permukaan akan fenomena sikap kontra sebagian masyarakat yang tetap aktif melaksanakan salat berjemaah di beberapa masjid di Kota Makassar. Masjid Nurul Huda di Jl. Barukang di Kel. Gusung, Kec. Ujung Tanah, Kota Makassar, termasuk masjid yang dipenuhi oleh ratusan jemaah yang melaksanakan Salat Tarawih. Padahal melaksanakan salat tarawih di rumah jauh lebih utama berjemaah bersama keluarga, terlebih di masa pandemi COVID-197.

Pemandangan miris itu terlihat jelas ketika petugas datang untuk membubarkan mereka, namun tanpa rasa khawatir justru ratusan warga

\footnotetext{
3"Naming The Coronavirus Disease (COVID-19) And The Virus That Causes It", Situs Resmi World Heath Organization (WHO). https:/www.who.int/emergencies/diseases/novelcoronavirus-2019/technical-guidance/naming-the-coronavirus-disease-(covid-2019)-and-thevirus-that-causes-it (15 April 2020).

${ }^{4}$ World Heath Organization (WHO), Coronavirus Disease (COVID-19) Outbreak Situation. https://www.who.int/emergencies/diseases/novel-coronavirus-2019 (16 April 2020).

${ }^{5}$ Presiden Republik Indonesia, Keputusan Presiden Republik Indonesia Nomor 11 Tahun 2020 Tentang Penetapan Kedaruratan Kesehatan Masyarakat Corona Virus Disease 2019 (COVID-19).

${ }^{6}$ Presiden Republik Indonesia, Keputusan Presiden Republik Indonesia Nomor 12 Tahun 2020 tentang Penetapan Encana Nonalam Penyebaran Corona Virus Disease 2019 (COVID19) Sebagai Bencana Nasional.

${ }^{7}$ Hede, A. M. T., bin Badani Tempo, R., \& Rafi, I., "Hukum Pelaksanaan Salat Tarawih di Rumah Karena Wabah dan Membaca Al-Qur'an Melalui Mushaf dan HP Ketika Salat", BUSTANUL FUQAHA: Jurnal Bidang Hukum Islam 1, no. 2 (2020): 252.
} 
berdatangan dan berkumpul di depan masjid dan menolak untuk dibubarkan, akhirnya petugas dari aparat TNI, POLRI dan Pemerintah terpaksa meninggalkan tempat itu $^{8}$. Masjid lainnya adalah Masjid Ridha, Jl. Tamalate Raya, Kec. Rappocini, Kota Makassar, dengan fenomena yang serupa. Pada akhirnya, 3 (tiga) orang di antara jemaah di masjid ini terinfeksi COVID-19 setelah menjalani rapid test seusai melaksanakan ibadah berjemaah ${ }^{9}$.

Alasan-alasan yang disampaikan oleh masyarakat yang masih tetap menunaikan salat berjemaah di masjid pun cukup beragam. Ada yang berargumentasi dengan dalil berupa potongan-potongan ayat atau hadis dan ada juga yang sekadar berlogika dengan mengatakan bahwa, "Bagaimana mungkin fasilitas umum dan angkutan umum dibiarkan terbuka padahal peluang penularan virus di tempat-tempat itu sangat besar, jutaan orang melewati dan memegang pintu yang sama, memegang barang yang sama, sementara salat berjamaah di masjid yang jauh lebih steril dari penyebaran virus dilarang"10.

Keberadaan kelompok yang kontra ini diperkuat oleh argumentasi beberapa orang mubalig yang disampaikan melalui ceramah-ceramah mereka, baik secara langsung maupun melalui media online tentang tidak bolehnya meninggalkan salat berjemaah di masjid, termasuk Salat Jumat selama pandemi COVID-19. Bahkan, di antara mereka ada yang berpendapat bahwa negara yang melarang pelaksanaan Salat Jumat akan tersebar di dalamnya virus COVID-19 secara meluas dan tanpa batas, sebaliknya, negara yang tetap melaksanakan salat Jumat akan terjaga dari wabah ini, menolak bala bukan dengan meninggalkan kewajiban ${ }^{11}$. Argumentasi para mubalig tersebut bagaikan angin segar bagi masyarakat untuk membenarkan sikap kontra mereka terhadap kebijakan pemerintah.

Kelompok yang pro dengan kebijakan pemerintah dalam hal peniadaan Salat Jumat selama pandemi COVID-19, ditandai dengan adanya fatwa Majelis Ulama Indonesia (MUI) Provinsi Sulawesi Selatan ${ }^{12}$, kabupaten dan kota ${ }^{13}$ serta

${ }^{8}$ Detik News, Sejumlah Masjid di Kota Makassar Tetap Gelar Shalat Tarawih. https://makassar.kompas.com/read/2020/04/24/11214261/sejumlah-masjid-di-kota-makassar-

tetap-gelar-shalat-tarawih?page=all (14 Juni 2020).

9 Republika, Rapid test 3 jamaah Tarawih di Makassar Positif Covid-19, https://republika.co.id/amp/q9nc52384 (14 Juni 2020)

${ }^{10}$ Tribun Asia, Tidak Ada Alasan Lagi Shalat Jum'at dan Berjamaah Dilarang Di Masjid...!!! https://tribunasia.com/index.php/2020/04/25/tidak-ada-alasan-lagi-shalat-jumat-danberjamaah-dilarang-di-masjid/ (20 Juni 2020).

${ }^{11}$ Sahabat Muslim Channel Tv, Habib Umar Larangan Tentang Shalat Jum'at Karena Wabah Virus Korona Covid-19 Ambil I'tibar Nya Aamin. https://www.youtube.com/watch?v=O1irJ_6xeVk (09/07/2020).

${ }^{12}$ Majelis Ulama Indonesia (MUI) Provinsi Sulawesi Selatan, Himbauan Majelis Ulama Indonesia (MUI) Provinsi Sulawesi Selatan dalam Menyikapi Merebaknya Kasus COVID-19 No. U. 22/DP.P.XXI/IV/2020, Tanggal 1 April 2020. 
Surat Edaran dan Imbauan dari berbagai lembaga-lembaga Islam yang menjadikan fatwa MUI sebagai dasar kebijakan, seperti Nahdlatul Ulama ${ }^{14}$, Muhammadiyah $^{15}$, Dewan Masjid Indonesia ${ }^{16}$, Wahdah Islamiyah ${ }^{17}$ dan yang lainnya. Sementara pada tanggal 9 Juni 2020 M, diberitakan pula bahwa Sulsel telah mencetak rekor tertinggi pertambahan kasus pasien positif terpapar virus corona $^{18}$, dan beberapa lama seusai pemerintah bersama ulama mengimbau agar masyarakat tetap berada di rumah dan menghindari kerumunan dan atau pergumulan. Dengan demikian, tampaknya, implementasi Surat Edaran dan fatwa tersebut belum menuai hasil yang signifikan dalam menurunkan jumlah kasus COVID-19 di Sulawesi Selatan.

Berdasarkan fenomena di atas, maka dipandang penting untuk meluruskan sikap dan pernyataan sebagian masyarakat tersebut dengan melakukan kajian lebih jauh tentang hukum peniadaan pelaksanaan Salat Jumat selama pandemi COVID-19 dan hukum mematuhi kebijakan Gubernur Sulsel Nomor: 451.11/2057/2020 ditinjau dari perspektif maqāsid al-syarī ah sebagai falsafah yang paling mendasar dalam pembentukan syariat Islam. Sehubungan dengan ini, telah ditemukan pula beberapa penelitian terdahulu yang relevan dan mengkaji tentang pelaksanaan ibadah selama pandemi COVID-19.

Studi kasus yang dilakukan oleh Sudirman dan Muhammad Rusdi Rasyid telah meneliti tentang peniadaan kegiatan-kegiatan keagamaan selama pandemi COVID-19 berdasarkan perspektif dalil-dalil yang bersifat umum seperti terkait anjuran melakukan tindakan preventif dari suatu kemudaratan yang dapat terjadi, sikap yang dicontohkan oleh Nabi dalam menyikapi sebuah wabah, dan lain lain, yang kemudian diinduksikan ke dalam sebuah kesimpulan yang dipandang sebagai maqāsid al-syarī ah. Penelitian ini menyimpulkan bahwa jika dalam pelaksanaan suatu ibadah dapat membahayakan eksistensi jiwa maka perintah tersebut akan selalu melahirkan alternatif ${ }^{19}$. Penelitian lain yang serupa telah

${ }^{13}$ Dewan Pimpinan Majelis Ulama Indonesia Kota Makassar, Surat Edaran No. 100/SE/MUI-MKS/IV/2020 Himbauan Kepada Seluruh Umat Se-Kota Makassar Bergerak Bersama Memutus Mata Rantai Virus COVID-19, Tanggal 1 April 2020.

${ }^{14}$ Pengurus Besar Nahdatul Ulama, Instruksi Nomor: 3952/C.I.34/03/2020 Tentang Protokol NU Peduli COVID-19, Tanggal 25 Maret 2020.

${ }^{15}$ Pimpinan Pusat Muhammadiyah, Edaran Pimpinan Pusat Muhammadiyah Nomor 04/EDR/1.0/E/2020 Tentang Tuntunan Salat Idulfitri Dalam Kondisi darurat Pandemi COVID19, Tanggal 14 Mei 2020.

${ }^{16}$ Pimpinan Pusat Dewan Masjid Indonesia, Edaran ke-2 Untuk Mencegah Penyebaran COVID-19, Nomor. O61/PP DMI/A/III/2020, Tanggal 19 maret 2020.

${ }^{17}$ Pimpinan Pusat Wahdah Islamiyah, Imbauan Nomor: D. 1846/IL/I/07/1441.

${ }^{18}$ Tribun News. Sulsel Cetak Rekor Tertinggi Pertambahan Kasus Pasien Positif. https:/makassar.tribunnews.com/amp/2020/06/09/update-covid-19-sulsel-9-juni-2020-sulselcetak-rekor-tertinggi-pertambahan-kasus-pasien-positif (10 April 2020).

19 Sudirman dan Muhammad Rusdi Rasyid, "Resolusi Maqasid al-Syariah Terhadap Penanggulangan Virus Covid-19”, Tasamuh: Jurnal Studi Islam 12, No. 2 (2020): h. 253-431. 
dilakukan oleh Hudzaifah Achmad Qotadah yang berkesimpulan bahwa hifžu aldin (memelihara agama) lebih utama dari pada hif̧̣u al-nafs (memelihara jiwa atau nyawa $)^{20}$.

Sepintas lalu, kedua penelitian di atas tampak koheren dengan penelitian ini, jika dilihat dari sisi objek kajian dan pisau analisis yang digunakannya, namun sisi perbedaaanya, yang signifikan terdapat pada metode analisisnya dan sudut pandang lain terhadap objek kajiannya, yaitu eksistensi imbauan peniadaan Salat Jumat sebagai sebuah kebijakan pemerintah perpektif al-maqāsid alkulliyah (hikmah universal syariat) dan al-maqặsid al-juz'iyyah (hikmah parsial syariat), serta metode implementasi teori-teori maqạsid Imam al-Syạtibī dalam menentukan kualifikasi ibadah Salat Jumat sebagai sebuah perintah dalam agama jika dibandingkan dengan maqạsid keselamatan jiwa selama pandemi COVID-19, apakah berada pada kualifikasi ḍrūriyyah, hạjiyyah atau tậsīniyyah?.

Shubhan Shodiq, dalam kajiannya telah menganalisis kebijakan Pembatasan Sosial Berskala Besar (PSBB) yang di dalamnya diatur tentang peniadaan ibadah selama pandemi melalui penerapkan kaidah-kaidah fikih dan usul fikih semisal kaedah al-masyaqqah tajlib al-taisìr dan al-ḍarar yuzāl menyimpulkan bahwa hukum Islam membenarkan kebijakan trsebut berdasarkan pendekatan kaidah fikih dan usul fikih ${ }^{21}$. Sedangkan Muhamad Kumaidi, lebih spesifik mengimplemntasikan kaidah fikih la yunkaru tagayyur al-ạkām bitagayyuri al-azmān wa al-ahwāl terhadap persoalan ibadah di masa pandemi COVID-19. Muhamad Kumaidi menemukan bahwa di masa pandemi, kaidah ini menjadi dasar fleksibilitas syariat Islam yang sesuai dengan perkembangan dan keadaan zaman. Para ulama pun memiliki peranan penting dalam berijtihad memberikan solusi pencegahan melalui tata cara beribadah ${ }^{22}$. Sisi perbedaan kedua penelitian tersebut dengan penelitian ini terletak pada konsep hukum yang digunakan sebagai pisau analisis dan jenis kebijakan pemerintah yang mengatur pelaksanaan ibadah selama pandemi COVID-19.

Rahmatiah juga telah meneliti tentang implementasi Perda (Peraturan Daerah) Sulsel terkait minuman beralkohol menurut perspektif hukum Islam dalam disertasinya pada tahun 2014 M. Letak perbedaan disertasi tersebut dengan penelitian ini berada pada kebijakan yang dikaji dan konsep hukum Islam

${ }^{20}$ Qotadah, Hudzaifah Achmad. "Covid-19: Tinjauan Maqasid Al-Shariah Terhadap Penangguhan Pelaksanaan Ibadah Shalat di Tempat Ibadah (Hifdz al-Nafs Lebih Utama Dari Hifdz al-Din?)." Salam: Jurnal Sosial dan Budaya Syar-i 7, No.7 (2020): h. 659-672.

${ }^{21}$ Shubhan Shodiq, "Penanganan Covid-19 Dalam Pendekatan Kaidah Fikih dan Ushul Fikih: Analisis Kebijakan Pembatasan Sosial Berskala Besar di Biang Keagamaan”, Jurnal: alAdalah: Jurnal Hukum dan Politik Islam 5, No. 2 (2020): h. 113-134.

${ }^{22}$ Muhammad Kumaidi, "Implementasi Kaedah La yunkaru tagayyur al-ahkām bi tagayyuri al-ạ̣kām wa al-Aḥwāl Dalam Ibadah di Masa Pandemi”, Asas 1, No. 01 (2020): 65-82. 
yang dijadikan sebagai variabel independen penelitian masing-masing ${ }^{23}$. Tesis tentang analisis penggunaan vasektomi dan tubektomi menurut medis dan maqāsid al-syarī' ah yang ditulis oleh Siti Rochmah di Universitas Islam Negeri Sunan Ampel Surabaya tahun 2018 M. Perbedaan tesis tersebut dengan penelitian ini terletak pada objek kajian penelitian masing-masing ${ }^{24}$. Penelitian lainnya yang juga menggunakan konsep maqăsid al-syarī'ah adalah penelitian tentang sudut pandang maqāsid al-syarīah terhadap pelaksanaan Jaminan Pelayanan Kesehatan peserta BPJS (Badan Penyelenggara Jaminan Sosial) yang ditulis oleh Zulhijatur Rahmi pada tahun 2018 M. Sisi perbedaannya dengan penelitian ini juga terdapat pada objek penelitiannya ${ }^{25}$.

Dengan tinjauan dari beberapa penelitian di atas, maka dapat dipahami bahwa pada umumnya penelitian-penelitian tersebut memiliki kesamaan dari sisi kajian analisis hukum Islam pada suatu persoalan kontemporer. Sebagian lainnya memiliki kesamaan dari sisi penerapan teori maqāsid al-syarī ah yang digunakan. Akan tetapi belum ditemukan adanya penelitian yang serupa dengan penilitian ini, jika dilihat dari sisi objek kajian yakni peniadaan Salat Jumat dan kedudukannya sebagai sebuah kebijakan pemerintah, apakah harus harus ditaati atau tidak?. Aspek lain yang membedakannya adalah pada metode implementasi teori maqāsid yang digunakan. Walhasil, perbedaan sudut pandang yang dianalisis pada objek kajiannya dapat menentukan penggunaan teori maqāsid alsyarīah yang diterapkan, sehingga meskipun beberapa penelitian menggunakan konsep maqāsid al-syarīiah yang sama, maka teori maqāsid yang diimplementasikan belum tentu sama, tergantung karakter dan sisi objek yang dianalisisnya.

Penelitian ini berjenis penelitian kepustakaan (library research) dengan menggunakan pendekatan teologis-normatif atau pendekatan syar' $\bar{i}$ dan pendekatan filosofis. Data-data yang merupakan bahan primer adalah Surat Edaran Gubernur Sulsel Nomor: 451.11/2057/2020, Undang-Undang dan Peraturan-Peraturan Pemerintah, ayat-ayat Al-Qur'an, hadis-hadis Nabi saw. dan teori-teori maqāsid al-syarī ah dari kitab-kitab para ulama (kitab turats). Adapun sumber data sekunder yaitu literatur-literatur yang berfungsi sebagai interpretasi ayat, hadis, karya-karya ilmiah yang mengkaji tentang teori-teori maqāsid alsyarī ${ }^{\prime}$ ah, hasil-hasil penelitian, jurnal ilmiah, media cetak maupun media online.

${ }^{23}$ Rahmatiah, HL, "Studi Kritis terhadap Pelaksanaan Peraturan Daerah tentang Minuman Beralkohol di Provinsi Sulawesi-Selatan (Perspektif Hukum Islam)", Disertasi (Universitas Islam Negeri Alauddin Makassar, 2014).

${ }^{24}$ Siti Rochmah, "Penggunaan vasektomi dan tubektomi perspektif medis dan maqasid alshari'ah", Disertasi (UIN Sunan Ampel Surabaya, 2018).

${ }^{25}$ Zulhijatur Rahmi, "Pelaksanaan Jaminan Pelayanan Kesehatan Peserta BPJS Kesehatan Ditinjau dari Maqashid al-Syari'ah." Saqifah: Jurnal Hukum Ekonomi Syari'ah 3, No. 01 (2018): h. 97-104. 
Adapun langkah-langkah yang dilakukan dalam pengolahan data penelitian yaitu: (1) Mengumpulkan data dengan cara memeriksa literaturliteratur ilmiah yang memiliki korelasi dengan disiplin ilmu maqāsid al-syarī ah; (2) Mengklasifikasikan teori-teori maqạsid al-syarīah yang relevan dengan karakter kajian, khususnya dalam kitab al-Muwāfaqāt karya Imām al-Syāțibìi; (3) Mengimplementasikan nas-nas yang bersifat teori tersebut terhadap objek riset dan mengikatnya dengan interpretasi ulama. Dengan demikian, penelitian ini dilakukan untuk mengkaji hukum peniadaan Salat Jumat selama pandemi COVID-19 dan kedudukannya sebagai kebijakan pemerintah melalui Surat Edaran Gubernur Sulsel Nomor: 451.11/2057/2020, dan ditinjau berdasarkan relevansinya terhadap prinsip-prinsip maqāsid al-syarī ${ }^{\prime} a h$.

\section{PEMBAHASAN}

\section{Konsep Maqāsid al-Syarī'ah}

Menurut Imam al- Syātibìi, maqāșid al-syarī' $a h^{26}$ diketahui berdasarkan kajian yang bersifat istiqrä $\bar{i}$ (induktif) ${ }^{27}$ dalam memahami hikmah pada setiap partikular nas syariat melalui analisis ilat hukum yang terkandung di dalamnya pada setiap rumpun kajian syariat. Selanjutnya, hikmah-hikmah (maqāṣid) yang telah ditemukan tersebut diinduksikan ke dalam makna esensial dan universal, maka disimpulkanlah bahwa syariat Islam diturunkan untuk menjaga kemaslahatan agama, jiwa, keturunan, akal dan harta atau yang diistilahkan dengan al-maqāsid al-kulliyyah (maqāṣid universal). Adapun analisis ilat terhadap rincian-rincian syariat atau al-maqāṣid al-juz’iyyah (al-maqāṣid parsial), menurut al-Syătibī, jumlahnya tidak terhitung ${ }^{28}$.

Imām al-Syātibī, berkata tentang tujuan diturunkannya syariat Islam bahwa:

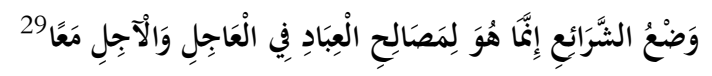

Artinya:

"Pembentukan syariat, hakikatnya adalah untuk kemaslahatan manusia di dunia sekaligus di akhirat".

${ }^{26}$ Al-Maqāsid al- ‘̄mmah adalah makna-makna dan hikmah-hikmah yang menjadi perhatian Pembuat Syariat pada semua proses pensyariatan atau sebagian besarnya. al-maqāsid al-khāsșah adalah cara-cara yang dikehendaki oleh Pembuat Syariat (Allah) dalam mewujudkan segala tujuan manusia yang bermanfaat, atau demi menjaga kemaslahatan-kemaslahatan umum mereka dalam tindakan-tindakan mereka secara khusus. Lihat Muhammad al-Ṭāhir ibn 'Asyūr, Maqāsid al-Syarī'ah al-Islāmiyyah (Cet. IV; Tūnis: Dār Suhnūn li al-Nasyr wa al-Tauzì', 2012, h.55 dan h. 163.

${ }^{27}$ Ibrāhīm ibn Mūsa al-Garnāți al-Syatibì, al-Muwāfaqāt, Jilid. 2 (Cet. II; al-Riyāḍ: Dār ibn al-Qayyim li al-Nasyr wa al-Tauzi', 2006), h. 12.

${ }^{28}$ Ibrāhīm ibn Mūsa al-Garnāṭi al-Syatibìi, Jilid. 2, al-Muwāfaqāt, h.13.

${ }^{29}$ Ibrāhīm ibn Mūsa al-Garnātịi al-Syatibìi, Jilid.2, al-Muwāfaqāt, h. 9. 
Menurutnya, maqāṣid fì al-tasyrī atau hikmah dalam pembentukan setiap syariat adalah:

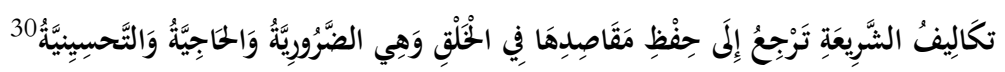

Artinya:

"Segala takālif (beban) syariat berorientasi untuk menjaga maqāșidnya terhadap manusia yaitu kemaslahatan yang bersifat ḍarūri (primer), hạjij (sekunder) dan tahsinin (tersier)".

\section{Al-Maqāṣid al-Ḍarūriyyah (Primer)}

Al-Maqāsid al-ḍarūiyyah adalah maksud syariat dalam menjaga kemaslahatan yang paling mendasar demi keberlangsungan hidup manusia yang harus terwujudkan. Sebab jika tidak, maka dapat menyebabkan ketidakseimbangan kehidupan di dunia yang berimbas pada kemaslahatan kehidupan di akhirat. Yang dimaksud dengan al-maqăsid al-darüriyyah tersebut adalah: hifẓu al-din (menjaga agama), hifẓu al-nafs (menjaga jiwa), hifẓu al-nasl (menjaga keturunan), hif̧u al-māl (menjaga harta) dan hif̧u al-'aql (menjaga akal). Kemaslahatan ini, menurut al-Syāțibì adalah kemaslahatan yang diperhitungkan oleh setiap agama.

Dalam menjaga al-maqāsid al-ḍarūriyyah, konsep tasyrī‘ (pembentukan syariat) dilakukan melalui dua aspek, yaitu aspek keberadaan dan ketiadaannya. Memelihara dari aspek keberadaannya yaitu dengan melakukan hal-hal yang bisa mewujudkan kemaslahatan itu sekaligus melestarikannya. Sebagai contoh, dalam menjaga kemaslahatan al-din dari aspek wujudnya, adalah dengan beiman, bersyahadat, menjaga salat dan mengeluarkan zakat dan berhaji. Dalam memelihara jiwa dari aspek wujudnya, adalah dengan menjaga kebutuhan sandang, pangan dan papan. Sedangkan memelihara dari aspek ketiadaannya adalah dengan menjauhkan hal-hal yang bisa mengakibatkan rusak atau hilangnya kemaslahatan yang telah ada. Contoh dalam menjaga al-din adalah ditegakkannya jihad dan kisas bagi orang yang murtad, dan dalam menjaga jiwa adalah penegakan hukum kisas dan diat (denda) bagi pelaku pembunuhan ${ }^{31}$.

\section{Al-Maqāṣid al-Ḥājiyyah (sekunder)}

Maqāsid al-hājiyyah adalah kemaslahatan yang dimaksudkan oleh syariat dalam bentuk kebutuhan manusia agar keberlangsungan hidup lebih sejahtera dan lebih lapang. Jika kemaslahatan ini tidak terpelihara maka dapat menyebabkan kehidupan yang sempit dan berat, sekalipun ketiadaannya tidak sampai menyebabkan mafsadah yang besar yang lebih esensial dan bersifat

\footnotetext{
${ }^{30}$ Ibrāhīm ibn Mūsa. Al-Garnāṭi al-Syatibī, Jilid. 2, al-Muwāfaqāt, h. 17.

${ }^{31}$ Ibrāhìm ibn Mūsa al-Garnāți al-Syatibì, Jilid.2, al-Muwāfaqūt, h. 17-18.
} 
darurat. Sebagai contoh, dalam hal ibadah, disyariatkannya rukhsah ketika berada dalam kondisi yang sulit seperti sakit atau safar. Dalam hal 'àdāt (kebiasaan), seperti dibolehkannya menikmati makanan yang halal, pakaian, tempat tinggal dan kendaraan. Dalam hal muamalah, seperti dibolehkannya utang-piutang, jual beli salam, dan dalam perkara jināyāt, seperti kewajiban diat terhadap ahli waris dan yaminn al-qasāmah ${ }^{32}$.

\section{Al-Maqāsid al-Tahsininiyyah (tersier)}

Al-Maqāsid al-taḥsiniyyah adalah jenis kemaslahatan yang sebaiknya diwujudkan untuk kehidupan yang lebih baik, dan meniadakan segala hal yang ditolak oleh akal sehat. Contohnya adalah menjaga kebersihan, menggunakan pakaian yang terlihat indah, melakukan ibadah-ibadah sunah seperti sedekah. Menjauhi tempat-tempat yang kotor, tidak berlebihan (isräf) dalam hal konsumsi. Tidak membunuh wanita, anak-anak, ahli ibadah dalam berjihad ${ }^{33}$.

Kemaslahatan yang bersifat tersier ini adalah penyempurna dari kemaslahatan sekunder, dan kemaslahatan sekunder adalah penyempurna dari kemaslahatan primer. Dengan kata lain, kemaslahatan tersier dan sekunder ibarat anggota badan (al-sifah) bagi tubuh (al-mausüff) yang merupakan kemaslahatan primer, sehingga kemaslahatan al-hājiyyah dan al-tahsinniyyah yang hanya berperan sebagai pelengkap tidak boleh didahulukan jika dapat mengakibatkan kemudaratan terhadap kemaslahatan al-darüriyyah ${ }^{34}$. Kedua jenis kemaslahatan al-häjijyyah (sekunder) dan al-taḥsiniyyah (tersier) bagaikan pelindung yang melingkari kemaslahatan al-dārüriyyah (primer). Inilah yang diistilahkan oleh alSyaṭibī dengan al-maqāsid al-kulliyyah dalam maqāsid al-syarī ah.

\section{Analisis Peniadaan Salat Jumat Selama Pandemi COVID-19 Perspektif Maqāṣid al-Syari 'ah al-Kulliyyah.}

Substansi Surat Edaran Gubernur Sulsel mengandung sebuah maqāsid dalam menjaga keselamatan jiwa manusia, namun hal itu dilakukan dengan peniadaan pelaksaanaan ibadah Salat Jumat yang merupakan bagian dari maqāsid menjaga agama dari aspek wujudnya, salah satu ibadah yang sangat prinsip dalam pandangan kaum muslimin. Kontradiksi antara kedua maqāṣid ini menuai perbedaan persepsi di kalangan masyarakat, termasuk dari kalangan mubalig dan ulama yang menanggapi bahwa kebijakan tersebut tidak solutif menurut perspektif syariat.

\footnotetext{
${ }^{32}$ Ibrāhīm ibn Mūsa al-Garnāṭi al-Syatibī, Jilid.2, al-Muwāfaqāt, h. 17-24.

${ }^{33}$ Ibrahīim ibn Mūsa. Al-Garnāṭì al-Syatibì, al-Muwāfaqāt, juz. 2, h. 17-24.

${ }^{34}$ Ibrahīm ibn Mūsa al-Garnāți al-Syatibī, Jilid. 2, al-Muwāfaqāt, h. 25.
} 
Untuk mengetahui hakikat dan relevansi kebijakan tersebut dengan prinsip maqāṣid al-syarī ah, maka beberapa teori Imam al-Syātibi dipandang tepat untuk diimplementasikan, di antaranya adalah, Ia berkata:

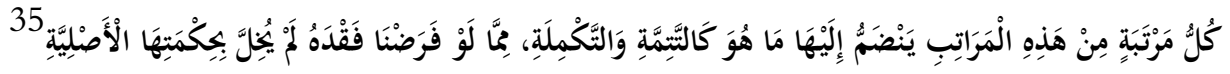

Artinya:

"Setiap tingkatan pada kualifikasi maqāșid tersebut terdapat di dalamnya maqāsid yang bersifat pelengkap (hajaji maupun tahsinini), yang jika diumpamakan pelengkap tersebut hilang maka hal itu tidak akan menyebabkan hilangnya asal syariat tersebut".

Implementasi teori tersebut terhadap persoalan ini bahwa, keselamatan jiwa masyarakat Sulsel telah berada pada kualifikasi al-darüri (darurat) dengan ditetapkannya sebagai zona merah penyebaran COVID-19, sedangkan kualifikasi ibadah Salat Jumat berada pada tingkatan al-hājiyyah, dengan alasan bahwa peniadaan Salat Jumat untuk sementara waktu selama pandemi COVID-19 demi menjaga keselamatan jiwa tidak berkonsekuensi pada hilangnya syariat salat lima waktu yang merupakan asalnya.

Syariat telah memberikan petunjuk tentang diperbolehkannya mengganti pelaksanaan Salat Jumat dengan Salat Zuhur pada kondisi tertentu, seperti ketika hujan deras dan tanah yang sangat berlumpur, atau orang yang sedang musafir. Dalam sebuah aśar dari Ibnu 'Abbās disebutkan bahwa ia pernah menyuruh muazin pada Hari Jumat untuk mengucapkan "al-salätu fi al-rihăal" (salatlah di rumah) sebagai pengganti ucapan "hayya 'alà al-ṣalāh” dan hal tersebut telah dilakukan oleh Nabi saw. ${ }^{36}$ Hasil penelitian Yusram juga mengatakan bahwa azan dalam masa pandemi COVID-19, hukumnya adalah fardu kifayah, dan dalam kondisi uzur berjemaah, ucapan "ḥayya 'alā al-salāh" dapat diganti dan atau ditambahkan di antaranya: Șallū fì rihālikum; Șallū fì buyūtikum; 'Alā Șallū fì alrihāl; dan al-salātu fi al-rị̣āl ${ }^{37}$. Sementara dari riwayat Ibnu Qudāmah alMaqdisi, beliau berkata bahwa Nabi saw. juga tidak mengerjakan salat Jumat ketika safar pada pelaksanaan haji wadā' yang bertepatan dengan hari Jumat, ia menjamak salat zuhur dan Asar di Arafah tanpa mengerjakan salat Jumat ${ }^{38}$.

Berdasarkan argumentasi di atas, maka dapat dipahami bahwa syariat Salat Jumat berada pada kualifikasi mukammil (komplemen) dari syariat salat

${ }^{35} \mathrm{Ibrāhīm} \mathrm{ibn} \mathrm{Mūsa} \mathrm{al-Garnāṭ̂i} \mathrm{al-Syatibi,} \mathrm{Jilid.2,} \mathrm{al-Muwāfaqāt,} \mathrm{h.} 24$.

${ }^{36}$ Muḥammad ibn Ismā'î̀l al-Bukharì, Sahịḥ al-Bukhari, Jilid. 1 (Cet. I; Dār Touq al-Najāh, 1422), dalam al-Maktabah al-Syāmilah ver. 3.62 [CD ROM], Muassasah al-Maktabah alSyāmilah, 2008, h. 134, hadis no. 668.

${ }^{37}$ Yusram, M., "Azan dan Kaifiatnya di Tengah Wabah Covid-19", BUSTANUL FUQAHA: Jurnal Bidang Hukum Islam 1 no. 2 (2020): h. 174.

38، Abdullah ibn Ahmad ibn Qudāmah al-Maqdisī, al-Mugnī, Jilid.2 (t.t; Maktabah alQāhirah, 1968), dalam al-Maktabah al-Syāmilah ver. 3.62 [CD ROM], Muassasah al-Maktabah alSyāmilah, 2008, h. 250. 
lima waktu yang merupakan syariat asalnya. Imam al-Syatibi kemudian menyebutkan sebuah teori dalam menyikapi dua maqāsid yang kontradiksi bahwa:

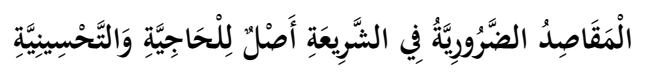

Artinya:

“Al-Maqāsid al-ḍarūriyyah dalam syariat adalah pokok dari (maqāṣid) alhājiyyah dan al-tahsininiyyah” (pelengkap) ${ }^{39}$.

Jika maqāṣid al-ḥäjiyyah dan al-tậsiniyyah adalah komplemen bagi maqāṣid al-darüriyyah, maka keduanya tidak boleh didahulukan jika berpotensi menghilangkan kemaslahatan asal yang lebih utama, dalam hal ini adalah maslahat utama keselamatan jiwa manusia. Muhammad ibn Husain al-Jizāni berkata ketika menjelaskan kaedah al-Syātibīi tersebut,

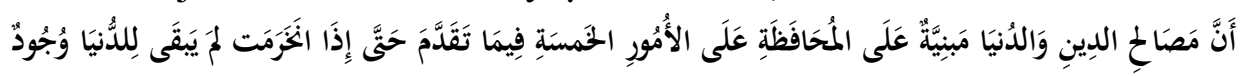

Artinya:

"Bahwa kemaslahatan agama dan kemaslahatan duniawi dibangun di atas pemeliharaan al-ḍarūriyyāt al-khams sebagaimana yang telah disebutkan, yang jika diibaratkan kemaslahatan itu hilang maka dunia pun akan ikut hilang" 40 .

Dari ucapan tersebut dapat dipahami bahwa segala hukum syariat baik yang berupa perintah maupun larangan berorientasi menjaga dan melestarikan kemaslahatan al-ḍarūriyyāt al-khams, sehingga, jika terjadi kontradiksi antara dua maqāsid atau kemaslahatan, maka yang didahulukan adalah kemaslahatan yang mengarah kepada pelestariannya, bukan yang meniadakannya. Walhasil, jika pelaksanaan salat Jumat yang merupakan maqăsid mukammil (pelengkap) dari pokok ibadah salat lima waktu dapat membahayakan eksistensi jiwa yang merupakan maqāsid al-ḍarüriyyah, maka salat Jumat boleh ditiadakan dan diganti dengan salat Zuhur di rumah hingga situasi kembali normal.

\section{Analisis Eksistensi Peniadaan Salat Jumat Selama Pandemi COVID-19 Sebagai Sebuah Kebijakan Pemerintah Perspektif Maqāsid al-Syari 'ah al-Juz'iyyah}

Salah satu kaedah yang disebutkan oleh Imam al-Syātibi dalam proses istinbat hukum nas-nas syariat adalah:

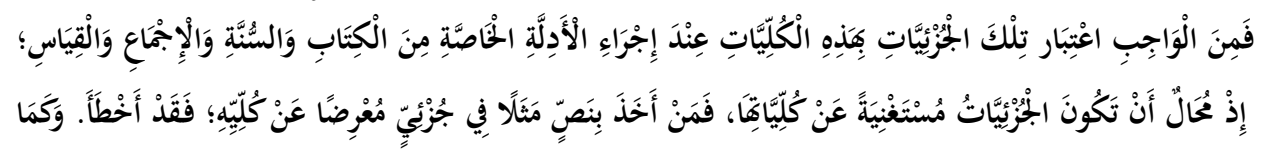

\footnotetext{
${ }^{39}$ Ibrāhīm ibn Mūsa al-Garnāți al-Syatibī, al-Muwāfaqāt, Jilid. 2 (Cet. II; al-Riyāḍ: Dār ibn al-Qayyim li al-Nasyr wa al-Tauzi', 2006), h. 31.

${ }^{40}$ Muhammad ibn Husain al-Jizani, Tahzib al-Muwafaqat (Cet. III; al-Dammam: Dar ibn al-Jauzi, 1430), h. 118.
} 


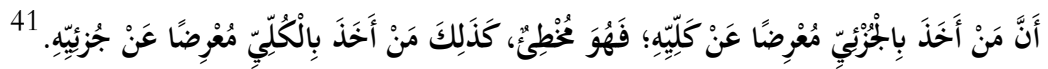

Artinya:

"Maka yang menjadi suatu hal yang wajib adalah, penetapan maqāsid parsial berdasarkan (keselarasannyabdengan) al-maqāsid al-kulliyyah (maqāsid komprehensif) dalam mengimplementasikan dalil-dalil khusus dari al-Qur'an, sunah, ijmak dan kias, sebab mustahil maqāsid parsial tersebut terlepas dari maqāsid komprehensifnya. Barang siapa yang mengabaikan nas yang bersifat komprehensif dan hanya berpegang pada nas parsial maka ia telah melakukan kesalahan, begitu pula sebaliknya."

Berdasarkan teori di atas, dipahami bahwa dalam proses istinbat hukum pada nas-nas syariat secara parsial tidak boleh menimbulkan kontradiksi dengan al-maqāșid al-kulliyyah (hikmah universal syariat), sebab syariat pada hakikatnya saling menguatkan.

Di antara argumentasi al-maqāsid al-juz'iyyah yang dapat diterapkan dalam persoalan ini adalah maqāsid kewajiban menaati pemimpin. Dalam Surat Edaran Gubernur Sulawesi Selatan Nomor: 451.11/2057/2020 disebutkan bahwa kebijakan didasarkan kepada fatwa Majelis Ulama Indonesia (MUI) Nomor 14 Tahun 2020 pada tanggal 21 Rajab 1441 H/16 Maret 2020 M tentang penyelenggaraan ibadah dalam situasi terjadi wabah COVID-1942. Jika terdapat dua pendapat ulama dalam satu persoalan, maka pendapat yang relevan dengan maqāsid persatuan umat di bawah satu kepemimpinan adalah lebih diutamakan. Hal tersebut dapat dipahami berdasarkan analogi hadis Nabi saw. tentang orang yang paling berhak menjadi imam dalam salat berjemaah:

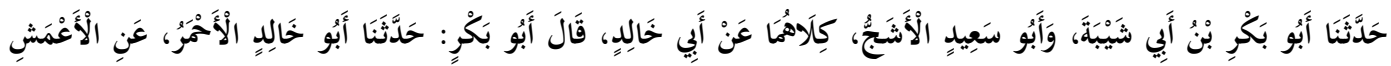

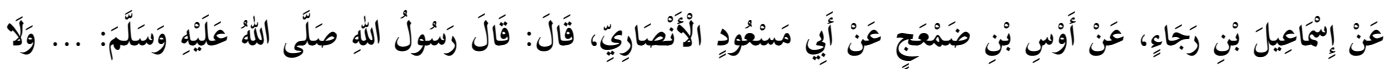

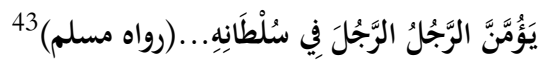

Artinya:

"Abu Bakr ibn Abī Syaibah dan Abu Sa'ìd al-Asyaj, keduanya (meriwayatkan) dari Abi Khālid, Abu Bakr berkata: Abu Khālid al-Aḥmar meriwayatkan kepada kami, dari al-a'masy, dari Ismā̄ l̀l ibn Rajā', dari Aus ibn Dam'aj, dari Abì Mas'ùd al-Anșāri, ia berkata, Nabi saw. telah

${ }^{41}$ Ibrahīm ibn Mūsa al-Garnāṭi al-Syatibīi, Jilid. 3, al-Muwāfaqāt, h. 175.

${ }^{42}$ Majelis Ulama Indonesia (MUI), fatwa Majelis Ulama Indonesia Nomor 14 Tahun 2020 tanggal 21 Rajab 1441 H/16 Maret 2020 M Tentang Penyelenggaraan Ibadah dalam Situasi Terjadi Wabah COVID-19.

${ }^{43}$ Muslim ibn al-Ḥajjāj al-Qusyairī, al-Naisābūrì, Saḥih Muslim, Jilid. 1 (t.t: Dār Ihyāa alTuras̄, t.th), dalam al-Maktabah al-Syāmilah ver. 3.62 [CD ROM], Muassasah al-Maktabah alSyāmilah, 2008, h. 465, hadis no. 673. 
bersabda, “...dan janganlah seseorang mengimami orang lain di bawah wilayah kekuasaannya...”(HR. Muslim)

Imam al-Nawawi mengomentari hadis tersebut bahwa ulama-ulama Mazhab Syafii berpendapat bahwa, jika penguasa atau wakilnya hadir dalam pelaksanaan salat berjemaah maka ia didahulukan dari tuan rumah, imam masjid dan yang lainnya, sebab wilayah kekuasannya lebih luas ${ }^{44}$, sekalipun ada yang lebih fakih darinya, sebagaimana 'Abdullah ibn 'Umar r.a. pernah menjadi makmum di belakang al-Hajjāj ibn Yūsuf, dengan alasan bahwa berjemaah disyariatkan lantaran bersatunya kaum mukminin di bawah satu ketaatan, sebab jika seseorang mengimami penguasa di bawah kekuasaannya, hal tersebut dapat merendahkan kedudukannya sebagai penguasa dan melepas ikatan ketaatan ${ }^{45}$, terutama dalam pelaksanaan Salat Jumat dan kedua Salat Idulfitri dan Iduladha.

Jika dicermati lebih jauh terhadap argumentasi di atas, maka dapat dipahami bahwa keputusan atau pendapat seorang pemimpin harus didahulukan daripada pendapat pribadi jika terkait kemaslahatan bersama, apalagi jika keputusan itu berdasarkan petunjuk dari para ulama dan para ahli. Argumentasi tersebut sejalan dengan maqāsid persatuan umat dan larangan berpecah belah, sehingga, jika terjadi persoalan besar terkait kemaslahatan publik, kemudian salah satu di antara fatwa para ulama dijadikan dasar kebijakan, maka hendaknya para ulama yang lain yang memiliki pendapat yang berbeda agar bersikap bijak dengan tidak mengekspos fatwanya demi kemaslahatan publik dan maqāsid persatuan umat, dan pada saat itu menjadi wajib bagi masyarakat untuk menaati kebijakan tersebut.

Salah satu aspek kemudaratan yang dapat ditimbulkan oleh fatwa individual yang kontradiktif dengan kebijakan pemerintah yang diekspos ke tengah masyarakat adalah, bahwa hal tersebut dapat menyebabkan ketidakpatuhan dan perpecahan di tengah masyarakat. Sebab karakter masyarakat dengan pemahaman agama yang rendah akan memancing mereka untuk berspekulasi sesuai standar pemahaman masing-masing kemudian menjadikan fatwa tersebut sebagai justifikasi sikap mereka mengabaikan kebijakan pemerintah yang berkonsekuensi pada kemudaratan yang besar.

Argumentasi yang lain, bahwa menjadikan fatwa Majelis Ulama Indonesia sebagai dasar kebijakan adalah relevan dengan maqāsid al-syarīiah. Allah swt. memerintahkan agar setiap persoalan agama dikembalikan kepada ulama, sebagaimana dalam firmanNya Qs. al-Nisā'/4: 83,

${ }^{44}$ Yahya ibn Syaraf al-Nawawi, al-Minhāj Syarh Saḥịh Muslim ibn al-Hajjajj, Jilid. 5 (Cet.II: Beirūt: Dār Ihyā' al-Turats al-'Arabī, 1392), h. 173.

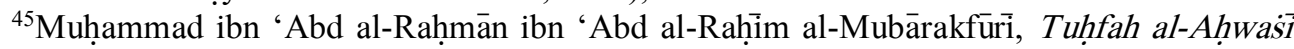
bi Syarh Jāmi’ al-Tirmiżí, jilid.2 (Beirūt: Dār al-Kutub al-“ilmiyyah, t.th), dalam al-Maktabah al-Syāmilah ver. 3.62 [CD ROM], Muassasah al-Maktabah al-Syāmilah, 2008, h. 29. 


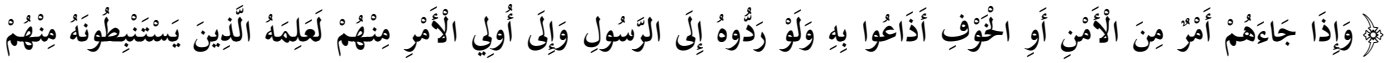

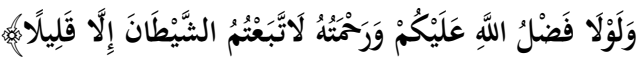

Terjemahnya:

“Dan apabila sampai kepada mereka suatu berita tentang keamanan atau pun ketakutan, mereka (langsung) menyiarkannya. Padahal apabila mereka menyerahkannya kepada Rasul dan ulil amri di antara mereka tentulah orang-orang yang ingin mengetahui kebenarannya (akan dapat) mengetahuinya (secara resmi) dari mereka (Rasul dan Ulil Amri). Sekiranya bukan karena karunia dan rahmat Allah kepadamu, tentulah kamu mengikuti setan, kecuali sebagian kecil saja (di antara kamu)"46.

Menurut Abdurraḥmān ibn Nāṣir al-Sa'di, ayat di atas adalah cara Allah swt. mengajarkan adab kepada hamba-Nya dalam menyikapi persoalan publik. Ia berkata:

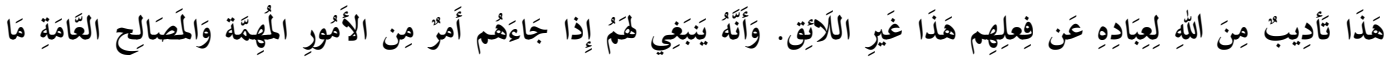

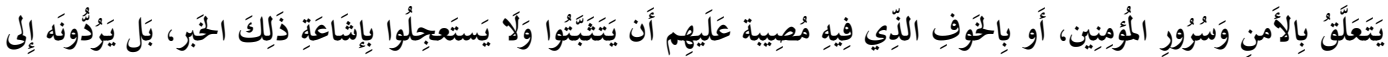

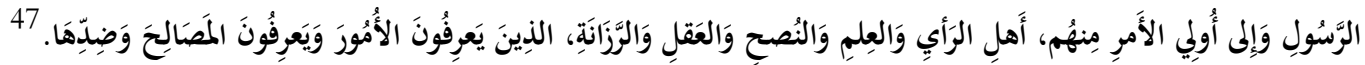

Artinya:

"Ini adalah pelajaran dari Allah swt. kepada hamba-hamba-Nya yang melakukan perbuatan yang tidak pantas, bahwa jika sampai kepada mereka kabar tentang sebuah persoalan penting dan kemaslahatan umum terkait rasa aman dan kebahagiaan orang-orang beriman atau rasa takut dari musibah yang menimpa mereka, agar menverifikasi terlebih dahulu kabar tersebut dan tidak menyebarkannya dengan tergesa-gesa. Akan tetapi, sepantasnya diserahkan kepada Rasul dan Ulil Amri di antara mereka, para ulama, cendikiawan, pakar dan ahli yang lebih mengetahui kemaslahatan dan kemudaratan yang terkandung dalam persoalan tersebut".

Sebuah pelajaran penting dapat disimpulkan dari argumentasi tersebut, khususnya bagi masyarakat, agar senentiasa merujuk kepada para ulama dalam memahami setiap persoalan agama. Sekalipun fatwa ulama tidak bersifat mengikat dan tidak mempunyai sanksi duniawi, akan tetapi mempunyai sanksi moril bagi yang tidak memiliki kapasitas untuk berfatwa. Dapat pula dipahami bahwa dalam menetapkan hukum persolan-persoalan terkait kemaslahatan umum, ijtihad kolektif lebih diutamakan daripada ijtihad individual, sebab ijtihad kolektif memiliki landasan dan referensi yang lebih kuat dibandingkan fatwa individual, sehingga lebih meyakinkan dalam menghasilkan produk fatwa yang

\footnotetext{
${ }^{46}$ Kementrian Agama Republik Indonesia, al-Qur'an Tajwid dan Terjemah, h. 91.

${ }^{47}$ Abd al-Raḥmān ibn Nāșir al-Sa'di, Taisìr al-Karìm al-Raḥmān fì Tafsìr Kalām alMannān (Cet. I; Beirūt: Muassasah al-Risalah, 2002), h. 190.
} 
berkualitas dan efektif menghadirkan kemaslahatan publik. Terlebih edaran dan aturan dari pemerintah dan MUI dalam penanganan COVID-19 sejatinya tidak menyelisihi syariat Islam ${ }^{48}$.

Sebagai penguat argumentasi-argumentasi di atas, terkait persoalan ketaatan kepada pemimpin, sebagian ulama berpendapat bahwa yang dimaksud dengan istilah $u \longdiv { i }$ al-amri yang wajib untuk ditaati adalah para pemimpin sekaligus para ulama, berdasarkan firman Allah swt. dalam QS. al-Nisā'/5: 59.

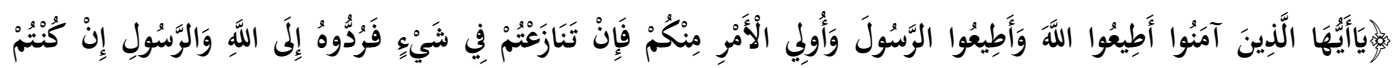

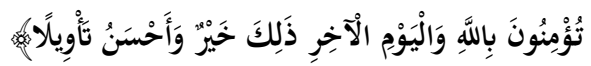

Terjemahnya:

“Wahai orang-orang yang beriman! Taatilah Allah dan taatilah Rasul (Muhammad), dan Ulil Amri (Pemegang Kekuasaan) di antara kamu. Kemudian, jika kamu berbeda pendapat tentang sesuatu, maka kembalikanlah kepada Allah (Al-Qur'an) dan Rasul (sunahnya), jika kamu beriman kepada Allah dan hari kemudian. Yang demikian itu lebih utama (bagimu) dan lebih baik akibatnya"49.

Ibnu Kasìr menyebutkan beberapa riwayat dari kalangan sahabat dan tabiin yang menafsirkan kata "wa uli al-amri minkum" dengan "ahlu al-fiqh wa al-dinn" atau ulama, seperti 'Abdullah ibn 'Abbās, 'Ali ibn Abì Ṭalhah, Mujahid, 'Ațā, al-Hạan al-Bașrì dan Abū al-Āliyyah, sehingga ia berpendapat bahwa yang dimaksud dengan uli al-amri yang wajib ditaati adalah penguasa dan ulama, ia berkata:

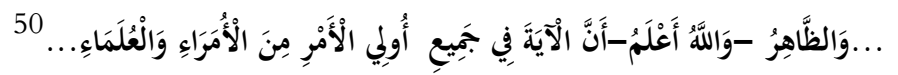

Artinya:

“...Dan zahirnya (pendapat yang rajih) -wallahu 'a'lam- bahwa ayat tersebut mencakup uli al-amri dari kalangan umara dan ulama...”

Ibnu Kasīr selanjutnya menukil sebuah hadis yang diriwayatkan oleh Abu Hurairah r.a. yang menerangkan bahwa ketaatan kepada pemimpin adalah bahagian dari ketaatan kepada Nabi saw.

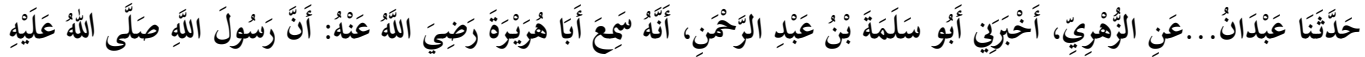

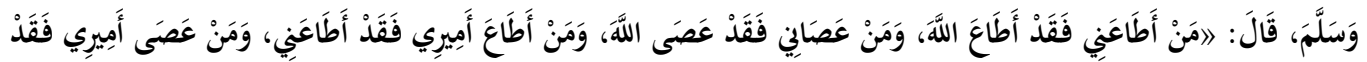

\footnotetext{
${ }^{48}$ Rajab, A. J., Nurdin, M. S., \& Mubarak, H., "Tinjauan Hukum Islam pada Edaran Pemerintah dan MUI dalam Menyikapi Wabah Covid-19”, BUSTANUL FUQAHA: Jurnal Bidang Hukum Islam 1 no. 2 (2020): h. 157.

${ }^{49}$ Kementrian Agama Republik Indonesia, al-Qur'an Tajwid dan Terjemah, h. 87.

${ }^{50}$ Ismā'ìl ibn 'Umar ibnu Kasīir al-Qurasyì al-Dimasyqì, jilid. 2, Tafsìr al-Qur'ān al- 'Azhìm (Cet. I; Beirūt: Dār al-kutub al-'Ilmiyyah, 1419), h. 345.
} 
Artinya:

" Abdān telah meriwayatkan kepada kami...dari al-Zuhrì, Abū Salamah ibn 'Abd al-Rahman telah mengabarkan kepadaku, bahwa ia telah mendengar Abū Hurairah -radiallahu 'anhu, bahwa Rasulullah saw. telah bersabda: "Barang siapa menaatiku maka ia telah menaati Allah, barang siapa bermaksiat kepadaku maka ia telah bermaksiat kepada Allah, dan barang siapa yang menaati pemimpinku maka ia telah menaatiku, barang siapa bermaksiat kepada pemimpinku maka ia telah bermaksiat kepadaku." (Muttafaq 'alaih).

Menurut Ibnu Hajar, yang dimaksud dengan pemimpin dalam hadis tersebut adalah semua pemimpin yang adil dan menyeru kepada kebenaran, hal tersebut dipahami berdasarkan ungkapan Nabi saw. "fa qad atā'anī," (sesungguhnya ia telah menaatiku) ${ }^{52}$ sebab, tidak mungkin ketaatan kepada pemimpin dianggap sebagai bagian dari ketaatan kepada Nabi saw. jika bertentangan dengan syariatnya. Pendapat ini pula yang dikuatkan oleh Ibnu alQayyim al-Jauziyyah, ketika ia membahas tentang ketaatan kepada uli al-amri, sebagaimana dalam ucapannya:

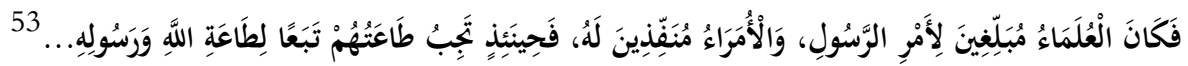

Artinya:

"Maka para ulama adalah penerus tugas Rasul, dan para umara yang merealisasikannya, pada saat itulah para umara wajib untuk ditaati sebagai bentuk ketaatan kepada Allah dan rasulNya”.

Dengan demikian, berdasarkan argumentasi di atas, maka dapat disimpulkan dawābit (ketentuan-ketentuan) dalam berfatwa dan menaati pemimpin terkait persoalan publik, yaitu:

1. Dalam menetapkan hukum suatu persoalan yang terkait kemaslahatan umum, ijtihad kolektif dengan melibatkan para ulama dan ahli lebih didahulukan dari pada ijtihad individual, sebab ijtihad kolektif didasarkan pada data dan referensi yang lebih lengkap dan akurat sehingga lebih meyakinkan untuk menghadirkan produk fatwa yang berkualitas.

${ }^{51}$ Muhammad ibn Ismā'il al-Bukharī, Sahīh al-Bukhari, Jilid. 9, hadis no. 7137, h. 61. Muslim bin al-Hajjāj al-Naisabūri, Sahih Muslim, juz. 3, h. 1466, hadis no. 1835.

${ }^{52}$ Aḥmad ibn 'ATi ibn Hajar al-'Asqalanī, Fatḥ al-Bārì Syarḥ Saḥịh Bukharì, Jilid.13 (Beirūt: Där al-Ma'rifah, 1379), dalam al-Maktabah al-Syāmilah ver. 3.62 [CD ROM], Muassasah al-Maktabah al-Syāmilah, 2008, h. 112.

${ }^{53}$ Muhammad bin Abi Bakr bin Ayyub bin Sa'ad ibnu Qayyim al-Jauziyyah, I'lām alMuwaqqi'īn 'an Rabb al-Ālamīn, Jilid. 2 (Cet. I; Beirūt: Dār al-Kutub al-'Ilmiyyah, 1991), dalam al-Maktabah al-Syāmilah ver. 3.62 [CD ROM], Muassasah al-Maktabah al-Syāmilah, 2008, h. 169. 
2. Fatwa ulama yang tidak dijadikan sebagai dasar kebijakan pemerintah tidak bersifat mengikat, akan tetapi jika fatwa tersebut telah dijadikan sebagai dasar kebijakan pemerintah demi kemaslahatan umum maka secara otomatis menjadi wajib untuk diimplementasikan dan ditaati oleh masyarakat.

3. Fatwa individual yang kontroversial tidak boleh diekspose ke tengah masyarakat jika dapat berpotensi menghambat implementasi kebijakan pemerintah dalam menghadirkan kemaslahatan umum yang lebih besar.

4. Wajib menaati kebijakan pemimpin selama kebijakannya relevan dengan maqāṣid al-syarī'ah.

\section{KESIMPULAN}

Berdasarkan metode istiqrāi (induktif) terhadap nas-nas syariat, dipahami bahwa prinsip utama maqāṣid al-syarīah berorientasi kepada kemaslahatan manusia di dunia dan di akhirat melalui pemeliharaan dan pelestarian al-ḍarūriyyāt al-khams yaitu: agama, jiwa, keturunan, akal dan harta. Syariat Islam dalam menjaga kelima hal tersebut membagi kemaslahatan dalam tiga kualifikasi, yaitu: al-maslahah al-darüriyyah (kemaslahatan primer), almașlaḥah al-hājiyyah (kemaslahatan sekunder) dan al-maslahah al-tahsiniyyah (kemaslahatn tersier). Pemeliharaan dan pelestarian dilakukan melalui dua aspek, yaitu aspek keberadaan dan ketiadaannya. Dari aspek keberadaannya yaitu dengan tasyr̄i (pensyariatan) perihal yang dapat mewujudkan sekaligus melestarikan kemaslahatan itu. Sedangkan dari aspek ketiadaannya, yaitu dengan menjauhkan hal-hal yang bisa mengakibatkan rusak atau hilangnya kemaslahatan yang telah ada. Dalam proses tasy $\bar{r} \ddot{~}$ dan istinbat hukum, terdapat dua teori maqāṣid yang menjadi teori dasar, yaitu: al-maqāṣid al-kulliyyah (maqāṣid universal) dan al-maqāșid al-juz'iyyah (maqāṣid parsial), kedua teori ini memiliki korelasi yang saling menguatkan dalam menghadirkan kemaslahatan manusia sebagai prinsip utama syariat.

Keselamatan jiwa berada pada kualifikasi al-ḍarüri (darurat) berdasarkan penetapan suatu wilayah sebagai zona merah penyebaran COVID-19, sedangkan kualifikasi ibadah Salat Jumat berada pada tingkatan al-häjiyyah (komplemen), dengan alasan bahwa peniadaan Salat Jumat tidak berkonsekuensi pada hilangnya syariat salat lima waktu yang merupakan asalnya, dengan diperbolehkannya untuk diganti dengan Salat Zuhur.

Peniadaan Salat Jumat sebagai sebuah kebijakan Gubernur Sulsel yang tercantum dalam Surat Edaran Nomor: 451.11/2057/2020 dalam upaya memutus mata rantai penyebaran COVID-19 adalah relevan dengan maqāsid al-syarī ah, baik perspektif al-maqāsid al-kulliyyah (universal) maupun perseptif al-maqāsid al-juz'iyyah (parsial). Dengan demikian, sikap sebagian masyarakat yang kontra terhadap kebijakan tersebut dan telah menghambat implementasinya adalah 
bertentangan dengan prinsip maqāṣid al-syarīiah, sekaligus menjadi indikasi rendahnya tingkat pemahaman masyarakat terhadap maqāsid al- al-syarī ah.

Ketidakpahaman masyarakat tentang prinsip maqāsid al-syarī ah adalah sebuah "penyakit" yang sangat potensial menyebabkan terjadinya banyak korban. Sementara persoalan-persoalan syariat yang bersifat kontemporer dan terkait kemaslahatan publik selalu memiliki korelasi dengan prinsip-prinsip maqāsid alal-syarīah. Untuk itu, pemerintah diharapkan untuk segera mengupayakan solusinya. Sosialisasi terhadap prinsip-prinsip maqāsid al-syarī'ah kepada masyarakat baik melalui aspek kelembagaan maupun individual para ulama, mubalig, pakar dan ahli bisa menjadi sebuah alternatif. Sebab, fenomena seperti ini telah terbukti membahayakan jiwa manusia dan setiap saat dapat terulang kembali.

\section{DAFTAR PUSTAKA}

Al-'Asqalani, Ahmad ibn 'Ali ibn Hạar. (1379 H). Fatḥ al-Bāri Syarḥ Șahị̣̂h Bukharīi. Beirūt: Dār al-Ma'rifah. Dalam al-Maktabah al-Syāmilah ver. 3.62 [CD ROM], Muassasah al-Maktabah al-Syāmilah, 2008.

Al-Bukharì, Muḥammad ibn Ismā'ìl. (1422 H). Saḥịh al-Bukhari. Dār Touq alNajāh. Dalam al-Maktabah al-Syāmilah ver. 3.62 [CD ROM], Muassasah alMaktabah al-Syāmilah, 2008.

Al-Mubārakfūrì, Muhammad ibn 'Abd al-Raḥmān ibn 'Abd al-Raḥim. (t.th). Tuḥfah al-Aḥwasīi bi Syarḥ Jämi' al-Tirmiżī. Beirūt: Dār al-Kutub al"ilmiyyah.

Al-Nawawi, Yahya ibn Syarf. (t.th). Sahih Muslim bi Syarh al-Nawawī. Dār alTaqwā li al-Nasyr wa al-Tauzi'.

Al-Sa'di, Abd al-Raḥmān ibn Nāṣir. (1420 H). Taisīr al-Karīm al-Raḥmān fī Tafsìr Kalām al-Mannān. Muassasah al-Risālah.

Al-Syatibī, Ibrahīm ibn Mūsa al-Garnātịi. (2006 M). al-Muwāfaqāt. Al-Riyāẹ: Dār ibn al-Qayyim li al-Nasyr wa al-Tauzi'.

Abi Bakr al-Qurțubi, Muḥammad bin Aḥmad. (1964 M). Al-Jāmi' li Ahkām alQur'ān. Al-Qāhirah: Dār al-Kutub al-Miṣriyyah. Dalam al-Maktabah alSyāmilah ver. 3.62 [CD ROM], Muassasah al-Maktabah al-Syāmilah, 2008.

Hede, A. M. T., bin Badani Tempo, R., \& Rafi, I. (2020). Hukum Pelaksanaan Salat Tarawih di Rumah Karena Wabah dan Membaca Al-Qur'an Melalui Mushaf dan HP Ketika Salat. BUSTANUL FUQAHA: Jurnal Bidang Hukum Islam, 1(2), 251-261.

Ibnu 'Asyūr, Muḥammad al-Ṭāhir. (2012 M).Maqāsid al-Syarì'ah al-Islāmiyyah. Tūnis: Dār Suḥnūn li al-Nasyr wa al-Tauzi', 
Ibnu Qayyim al-Jauziyyah, Muhammad bin Abi Bakr bin Ayyub bin Sa'ad. (1991). I'lām al-Muwaqqi'in 'an Rabb al-Āamīn. Beirūt: Dār al-Kutub al'Ilmiyyah.

Ibnu Qudāmah al-Maqdisī, 'Abdullah ibn Ahmad. (1988). Al-Mugnī. AlQāhirah, Maktabah al-Qāhirah. Dalam al-Maktabah al-Syāmilah ver. 3.62 [CD ROM], Muassasah al-Maktabah al-Syāmilah, 2008.

Kementrian Agama Republik Indonesia. (2015). Al-Qur'an Tajwid dan Terjemah. Jakarta: Perum Percetakan Negara RI.

Majelis Ulama Indonesia (MUI), fatwa Majelis Ulama Indonesia Nomor 14 Tahun 2020 tanggal 21 Rajab 1441 H/16 Maret 2020 M Tentang Penyelenggaraan Ibadah dalam Situasi Terjadi Wabah COVID-19.

Presiden Republik Indonesia, Keputusan Presiden Republik Indonesia Nomor 11 Tahun 2020 Tentang Penetapan Kedaruratan Kesehatan Masyarakat Corona Virus Disease 2019 (COVID-19).

Presiden Republik Indonesia, Keputusan Presiden Republik Indonesia Nomor 12 Tahun 2020 tentang Penetapan Encana Nonalam Penyebaran Corona Virus Disease 2019 (COVID-19) Sebagai Bencana Nasional.

Sudirman dan Muhammad Rusdi Rasyid. (2020). Resolusi Maqasid al-Syariah Terhadap Penanggulangan Virus Covid-19. Tasamuh: Jurnal Studi Islam 12, No. 2, 253-431.

Qotadah, Hudzaifah Achmad. (2020). Covid-19: Tinjauan Maqasid Al-Shariah Terhadap Penangguhan Pelaksanaan Ibadah Shalat di Tempat Ibadah (Hifdz al-Nafs Lebih Utama Dari Hifdz al-Din?). Salam: Jurnal Sosial dan Budaya Syar-i 7, No.7, 659-672.

Shodiq, Shubhan. (2020). Penanganan Covid-19 Dalam Pendekatan Kaidah Fikih dan Ushul Fikih: Analisis Kebijakan Pembatasan Sosial Berskala Besar di Biang Keagamaan. Jurnal: al-Adalah: Jurnal Hukum dan Politik Islam 5, No. 2, 113-134.

Kumaidi, Muhammad. (2020). Implementasi Kaedah La yunkaru tagayyur alaḥkām bi tagayyuri al-aḥkām wa al-Aḥwāl dalam Ibadah di Masa Pandemi. Asas 1, No. 01, 65-82.

Rahmatiah, HL. (2014). Studi Kritis Terhadap Pelaksanaan Peraturan Daerah tentang Minuman Beralkohol di Provinsi Sulawesi-Selatan (Perspektif Hukum Islam). Disertasi (Universitas Islam Negeri Alauddin Makassar).

Rajab, A. J., Nurdin, M. S., \& Mubarak, H. (2020). Tinjauan Hukum Islam pada Edaran Pemerintah dan MUI dalam Menyikapi Wabah Covid19. BUSTANUL FUQAHA: Jurnal Bidang Hukum Islam, 1(2), 156-173.

Rochmah, Siti. (2018). Penggunaan Vasektomi dan Tubektomi Perspektif Medis dan Maqasid al-Shari'ah. Disertasi (UIN Sunan Ampel Surabaya). 
Rahmi, Zulhijatur. (2018). Pelaksanaan Jaminan Pelayanan Kesehatan Peserta BPJS Kesehatan Ditinjau dari Maqashid al-Syari’ah. Saqifah: Jurnal Hukum Ekonomi Syari'ah 3, No. 01, 97-104.

Detik News. Sejumlah Masjid di Kota Makassar Tetap Gelar Shalat Tarawih. https://makassar.kompas.com/read/2020/04/24/11214261/sejumlah-masjiddi-kota-makassar-tetap-gelar-shalat-tarawih?page=all (14 Juni 2020).

Republika. Rapid test 3 jamaah Tarawih di Makassar Positif Covid-19. https://republika.co.id/amp/q9nc52384 (14 Juni 2020)

Tribun Asia. Tidak Ada Alasan Lagi Shalat Jumat dan Berjamaah Dilarang Di Masjid...!!!. https://ribunasia.com/index.php/2020/04/25/tidak-ada-alasanlagi-shalat-jumat-dan-berjamaah-dilarang-di-masjid/ (20 Juni 2020).

Tribun News. Sulsel Cetak Rekor Tertinggi Pertambahan Kasus Pasien Positif. https://makassar.tribunnews.com/amp/2020/06/09/update-covid-19-sulsel-9juni-2020-sulsel-cetak-rekor-tertinggi-pertambahan-kasus-pasien-positif (10 April 2020).

Usman, M. H., Aswar, A., \& Irawan, A. W. (2020). Syariat Islam dan Kemaslahatan Manusia di Era New Normal pada Kegiataan Keagamaan dan Pendidikan. FENOMENA, 12(1), 89-106.

World Heath Organization (WHO). Naming The Coronavirus Disease (COVID19) And The Virus That Causes It. https://www.who.int/emergencies/diseases/novel-coronavirus2019/technical-guidance/naming-the-coronavirus-disease-(covid-2019)-andthe-virus-that-causes-it (15 April 2020).

Yusram, M. (2020). Azan dan Kaifiatnya di Tengah Wabah Covid19. BUSTANUL FUQAHA: Jurnal Bidang Hukum Islam, 1(2), 174-196. 